\title{
Growth of Circulating Tumor Cell-Derived Colonies from Peripheral Blood of Melanoma Patients: Preliminary Characterization of Colony Composition
}

\author{
Wolfram E. Samlowski1,2*, John R. McGregor ${ }^{3}$, Suzanne T. Samlowski³, \\ Shweta Tharkar ${ }^{3}$, Shirley Shen ${ }^{4}$, Joel S. Bentz ${ }^{5}$ \\ ${ }^{1}$ Department of Oncology, Comprehensive Cancer Centers of Nevada, Las Vegas, USA \\ ${ }^{2}$ University of Nevada School of Medicine, Reno, USA \\ ${ }^{3}$ TrueCells LLC, Las Vegas, USA \\ ${ }^{4}$ Genomics Core Facility, University of Nevada Las Vegas, Las Vegas, USA \\ ${ }^{5}$ LMC Pathology, Las Vegas, USA \\ Email: *wsamlowski1@gmail.com
}

Received 12 April 2014; revised 27 May 2014; accepted 12 June 2014

Copyright (C) 2014 by authors and Scientific Research Publishing Inc.

This work is licensed under the Creative Commons Attribution International License (CC BY). http://creativecommons.org/licenses/by/4.0/

c) (i) Open Access

\section{Abstract}

Circulating tumor cells (CTC) are rarely detected in the blood of cancer patients, even though they are a direct harbinger of eventual patient demise. We developed an innovative CTC culture technology to allow more sensitive isolation, expansion, and characterization of viable colonies from patient blood. In this assay, the entire leukocyte fraction from $10 \mathrm{ml}$ of anticoagulated patient blood is placed into culture medium without any pre-selection. After 16 days in culture, CTC derived colonies are counted. As a proof-of-principle, blood samples from 58 Stage IIa-IV melanoma patients were tested. Ninety percent of these samples grew colonies. The colony numbers ranged from 0 - 308 (mean $63 \pm 9.5$ SEM). Ten normal volunteers had virtually no growth (mean $0.5 \pm 1.4$ colonies). Colonies were harvested using a micropipette for characterization. Tumor-cell containing spheroids were embedded in paraffin, sectioned, and stained with melanoma-specific mAb for histologic characterization. MITF proved to be the most consistent immunostain that identified melanoma cells in these colonies. A host-cell component in colonies was also identified using CD68 and CD43 mAb staining. Following enzymatic dissociation of colonies, a variety of immunostains were tested. Papanicolau staining proved most useful for identifying the abnormal nuclei of tumor cells. Flow cytometry could readily distinguish host and tumor cell populations based on DNA content and forward/side scatter in dissociated colonies. The stem cell marker ALDH1A1 associated with the aneuploid population, but CD45 was expressed on both diploid and aneuploid cells.

*Corresponding author.

How to cite this paper: Samlowski, W.E., et al. (2014) Growth of Circulating Tumor Cell-Derived Colonies from Peripheral Blood of Melanoma Patients: Preliminary Characterization of Colony Composition. Health, 6, 1467-1481.

http://dx.doi.org/10.4236/health.2014.612181 
The ability to repeatedly isolate CTC derived colonies from cancer patient blood samples opens the door to a novel type of long-term clinical monitoring. This novel CTC culture technology may prove useful to perform molecular characterization, assessment of treatment response, and testing of drug sensitivity and resistance in patients during treatment.

\title{
Keywords
}

\author{
Circulating Tumor Cells, CTC Colonies, CTC Cultures, Melanoma, Flow Cytometry, CTC Derived \\ Colonies
}

\section{Introduction}

At some point during tumor development, malignant cells gain the ability to enter the vasculature, circulate, extravasate and grow in distant organs [1]. These circulating tumor cells are believed to form metastasis in vital organs, which remains the major cause of cancer-related mortality. Metastatic cancer accounts for approximately 560,000 deaths/year in the United States [2] [3]. Using current techniques, circulating tumor cells (CTC) are rarely detectable in cancer patient blood. These CTC are believed to be a direct harbinger of eventual patient demise.

The presence of CTC in the blood of cancer patients was first suspected almost 2 decades ago, based on detection of tumor cell derived mRNA in cancer patient leukocytes using RT-PCR. These studies employed primers directed against tumor-related epithelial and melanoma genes (e.g., cytokeratin-19, tyrosinase) [4]. Whether this mRNA was derived from intact tumor cells could not be established. These assays lacked specificity, and quantitation was problematic. It was subsequently learned that illegitimate expression of these genetic markers or amplification of pseudogene products could cause false-positive test results [4].

Subsequently, techniques were developed to physically enrich and count rare CTC using monoclonal antibodies (mAb) against epithelial cell surface antigens. Detection of CTC in epithelial cancers has been facilitated by the availability of pan-reactive reagents, such as EpCAM mAb (CD326), which are not expressed on circulating leukocytes [5]. Using this approach, CTC were identified at a ratio of $\sim 1$ CTC $/ 10^{6}-10^{7}$ circulating leukocytes [6]. Rare CTC could be identified in advanced epithelial cancer patients, but not in normal controls or in patients with non-metastatic cancer [7].

Based on these observations, a CTC detection system has been commercialized by Veridex, LLC (now Johnson \& Johnson), using automated digital microscopy for three cancers. This test requires expensive equipment and proprietary reagents, which further limits the application. The CellSearch AutoPrep instrument immunomagnetically enriches cells expressing EpCAM from $7.5 \mathrm{~mL}$ of blood, fluorescently labels the enriched cells with DAPI, CD45-APC, and cytokeratin (CK)-PE, then resuspends the cells in a cartridge placed in the CellSearch MagNest. The design of the magnets guides the magnetically labeled cells to the analysis surface. The CellSearch MagNest chamber is placed on the CellSearch Analyzer II instrument. This semi-automated fluorescence-based microscopy system acquires images to cover the complete surface area of the analysis chamber using a 10X objective. A computer identifies cells stained with both DAPI and PE and takes digital photographs for operator-based visual confirmation. In the Veridex assay, CTC are defined as nucleated cells that stain with DAPI and CK-PE, but exclude cells staining with the leukocyte marker CD45-APC.

Using the Veridex assay, investigators found that tiny numbers of CTC can be detected in patients with regionally advanced or metastatic breast, colon, and prostate cancer, because all three usually express EpCAM [8][10]. The number of CTC isolated was shown to correlate with cancer stage, progression and patient survival in these cancers [8] [10] [11]. Sequential CTC measurements were shown to have predictive value during treatment, as increases in CTC numbers preceded radiographic evidence of metastases [11] [12]. There was a correlation between increasing numbers of CTC ( $\geq 5$ CTC/7.5 ml blood) with decreased survival [8]-[10] [13] [14]. Decreases in CTC counts correlated with a lowered PSA and radiologic response in prostate cancer [9]. The FDA therefore approved the use of the Cell Search EpCAM-based CTC assay in these three cancers as a prognostic and predictive laboratory test. More recently, other microscope-based, microfluidic and microfilter-based technologies have been considered for CTC detection and recovery [15]-[17] . 
However, there are currently problems with EpCAM-based CTC detection. For example, 5\% - 15\% of breast, colon, and prostate cancers express low levels of EpCAM, making the CTC in this patient group virtually undetectable [18] [19]. Konigsberg et al showed that there is substantial variability in EPCAM expression on the surface of individual CTC, therefore making CTC detection inconsistent or unreliable [20]. This assay has not been useful for detection of CTC in cancers including melanoma, renal cancer, or sarcoma because these cancers don't express EpCAM. It is highly likely that a CTC assay specific to these cancers would also correlate with prognosis, as well as provide a marker for treatment response. Another problem with the current CTC assay technology is that it yields only tiny numbers of tumor cells. These cells are badly damaged by the isolation process and fixatives, and are non-viable, limiting their usefulness for further biologic studies.

We therefore attempted to develop a cell-culture based CTC isolation technology, without making any a priori assumptions about potential tumor cell antigen expression. We hypothesized that a cell culture-based assay could be used to consistently and reliably grow CTC derived colonies and might provide a more robust prognostic and predictive marker for cancer patients.

\section{Materials and Methods}

\subsection{Clinical CTC Culture Protocol}

Patients with metastatic cancer were invited to participate in an IRB approved protocol. This study is reviewed and approved annually by the University Medical Center of Southern Nevada IRB and is registered in the National Cancer Institute (NCI) clinical trials database (http://www.clinicaltrials.gov/show/NCT01528774). Following signed informed consent, $30-40 \mathrm{ml}$ of anticoagulated blood was drawn into four standard vacutainer tubes. These blood samples were sent to TrueCells LLC, Las Vegas, NV for processing within $24 \mathrm{~h}$ of the blood draw. The white blood cell fraction in each vacutainer tube of blood was separated by Ficoll/Hypaque centrifugation, and split into eight replicate cultures containing proprietary TrueCells medium (patent pending). The buffy coat, the white blood cell fraction of blood, is known to contain CTC [21]. Cultures were then incubated in a $5 \% \mathrm{CO}_{2}$ incubator at $37^{\circ} \mathrm{C}$.

\subsection{Harvesting and Analysis of CTC Derived Colonies}

After 16 days in culture, tumor colonies were counted using an inverted microscope. To standardize colony identification, a "colony" was defined as greater than $0.2 \times 0.2 \mathrm{~cm}\left(0.04 \mathrm{~cm}^{2}\right)$ via an ocular grid. Each colony represented $>100$ cells. A yield of 140,000 - 4,000,000 cells grown from colonies derived from $10 \mathrm{ml}$ blood was typical after 16 days.

The following experiments were performed: 1) Intact tumor spheroid colonies were isolated using a micropipette, washed and fixed. Histologic cross-sections were prepared for a variety of stains and microscopic analysis. 2) Colonies were isolated and disassociated in $1 \mathrm{ml}$ of Accutase for 10 minutes (Life Technologies, Grand Island, NY). These dissociated cells were washed, fixed and permeabilized to prepare slides for Papanicolaou staining and immunostains and in 3) suspensions of dissociated cells from CTC colonies were stained with propidium iodide (PI) and monoclonal antibodies, such as ALDH1A1 and CD45, for flow cytometric analysis.

\subsubsection{Preparation of Tumor Spheroid Colonies for Histologic Analysis}

CTC derived colonies were harvested using a sterile micropipette. Colonies were placed in CytoLyt solution (Hologic, Inc., Marlborough, MA) and cytocentrifuged. The pellet was formalin-fixed, and embedded in paraffin as a cellblock. A series of $5 \mu \mathrm{m}$ sections were prepared. A slide stained with hematoxylin and eosin was used to evaluate pathology of the spheroid. Slides were also stained with the melanoma markers MITF (microopthalmia transcription factor, clone C5/D5, rabbit-anti-human, Ventana Medical Systems, Tucson), HMB45 (melanoma antigen, clone HMB45, Cell Marque, rabbit-anti-human), S100 (melanoma antigen, clone 4C4.9, Ventana, rabbit-anti-human), and Mart-1/Melan A (melanoma antigen, clone A103, Ventana, rabbit-anti-human), using a BenchMark Ultra Staining system with the Optiview DAB hapten detection system. To identify any non-tumor cells in colonies, spheroids were also stained with Ventana rabbit mAb to CD68 (pan-macrophage), CD31 (endothelial cells), CD34 (hematopoietic stem cells), CD43 (PMN, monocytes, histiocytes), CD3 (T cells) and CD45 (leukocyte common antigen, clone RP2/18, Ventana, rabbit-anti-human pan hematopoietic cell marker). 
Slides stained with a non-specific primary plus the secondary detection reagent served as a specificity control.

\subsubsection{Preparation and Analysis of Single Cell Suspensions from CTC Derived Colonies}

After Accutase digestion of colonies, cell smears were prepared by allowing $50 \mu \mathrm{l}$ of a single cell suspension to settle onto a glass slide. After media was gently decanted and blotted, slides were air-dried and fixed in 95\% ethanol. Slides were then stained with Papanicolaou stain [22] or primary mAb, using a Bench Mark Ultra Staining system and the OptiView DAB hapten detection system (Ventana) and antibodies listed. Slides stained with a non-specific primary plus secondary detection reagent served as a specificity control.

\subsubsection{Flow Cytometric Analysis of CTC Derived Colony Cells}

DNA Analysis: Fixed and permeabilized cells (BD Cytofix/Cytoperm) were treated with $200 \mu \mathrm{g} / \mathrm{ml}$ RNAse (R4875, Sigma, St. Louis, MO) for 10 minutes. Propidium iodide (PI, P4864, Sigma St. Louis, MO) was added at a final concentration of $50 \mu \mathrm{g} / \mathrm{ml}$. Twenty thousand events were analyzed per sample using a FACSCalibur flow cytometer and data were analyzed using Flow Jo (Ashland, OR) software. Data was plotted showing PI fluorescence on a linear scale. Normal human leukocytes (diploid DNA) or M14 melanoma cells (aneuploid DNA) served as controls.

ALDH/CD45 Staining: In these experiments, cells were first stained with monoclonal antibodies prior to PI staining for DNA analysis. Cells were stained for either ALDH1A1 (sc-374076, Santa Cruz Biotechnology, Dallas, TX) using a FITC labeled anti-mouse secondary antibody for detection (sc-2010 Santa Cruz) or CD45 using APC-conjugated anti-CD45 (560973, BD Biosciences, San Diego, CA) at $5 \mu \mathrm{g} / \mathrm{ml}$ for 30 minutes, followed by extensive washes. Cells were subsequently fixed and permeabilized and stained with PI as described above. The cells were analyzed using a FACSCalibur flow cytometer (BD Biosciences, San Jose, CA) at the UNLV Genomics Core facility. Data analysis was subsequently performed using Flow-Jo software (Tree Star, Inc.). Unstained cells and cells stained with secondary antibody alone served as negative controls for flow cytometric gating.

\subsection{Modeling Colony Formation Using Leukocyte/Tumor Cell Line Coculture Model}

Our experiments demonstrated a host cell component in CTC derived colonies. We performed preliminary experiments to try to understand the potential contribution of host leukocytes to tumor colony formation. The melanoma cell line MALME was obtained from ATCC and adapted for growth in TrueCells medium. Varying numbers of MALME tumor cells were placed into CTC culture medium with $10^{6}$ normal donor leukocytes in triplicate cultures. MALME cells without cocultured feeder cells served as a control. Cells were cultured for 16 days, and cultures counted.

\section{Results}

\subsection{Patient Characteristics}

The individual patient characteristics are shown (Supplementary Data). Sixty patients signed consent to provide samples, although two patients never had samples drawn. The actual study cohort was 32 men and 26 women (58 patients). There were 53 Caucasians, 3 Hispanics, 1 Asian and 1 African-American. There were 43 skin melanomas, 5 unknown primary melanomas, 4 ocular, 4 mucosal and 2 acral melanomas. There were 7 Stage II patients (1 Stage IIa, 6 Stage IIb), 14 Stage III (Stage IIIb-8, Stage IIIc-6) and 37 Stage IV (Stage IVa-9, Stage IVb-2, Stage IVc-26).

Of the study cohort, 22 had BRAF mutations (21 V600E, 1 V600R). There were 6 patients with NRAS mutations and 1 with a C-KIT mutation. Biopsies failed to provide adequate tissue for sequencing in 3 patients and 12 patients were wild type at all loci tested. Tumors from 14 Stage II and III patients were not sent for sequencing.

\subsection{CTC Derived Colony Formation in Melanoma Patients}

Fifty-two of fifty-eight high-risk melanoma patients grew colonies from their blood samples (90\%). The patients who did not grow CTC derived colonies represented patients who were in remission (2 patients) or had very re- 
cently received anticancer therapy within a week of the blood draw (2 patients), potentially interfering with colony outgrowth. Two additional samples failed to grow colonies in patients with significant metastatic tumor burden for unclear reasons, which could represent possible technical failures. Ten normal volunteers (people without cancer) also provided blood samples under our IRB protocol and had a mean colony growth of $0.5 \pm 1.4$ colonies. These colonies appeared to be mature adipose cells, possibly derived from the vascular plug.

\subsection{Characterization of CTC-Derived Colonies Using Histologic Sections of Spheroids}

CTC-derived cultures were examined under a dissecting microscope on day 16 of culture and colonies were counted. The number of colonies ranged from 0 - 308, with a mean of $63 \pm 9.5$ (SEM). An example of a melanoma colony is shown (Figure 1(a)). The median number of colonies was $29 \pm 9.5$. Intact colonies were individually harvested with a micropipette and embedded in paraffin. Thin sections were prepared and stained with hematoxylin and eosin (Figure 1(b)), and parallel slides were stained with a series of melanoma directed mAb.

Microopthalmia transcription factor gave the most frequent positive results (MITF, Figure 1(c)). MITF mAb stained the nuclei in a significant percentage of tumor cells derived from CTC-derived culture colonies.

\subsection{Characterization of CTC-Derived Colonies by Dissociation and Staining of Individual Cells}

To verify that colonies grown from blood of metastatic cancer patients contained tumor cells, single cell suspensions were prepared by Accutase treatment of CTC derived colonies. The cell yield dissociation of colonies ranged between 140,000 - 4,000,000 cells from $10 \mathrm{ml}$ blood. The resulting single cell suspension was placed drop wise onto glass slides, air-dried and fixed in 95\% ethanol.

These slides were stained using Papanicolaou (PAP) stain to identify cells with abnormal nuclei (Figure 1(d)) [22]. This experiment suggested that CTC derived colonies represented a mixture of small blood derived leukocytes, plus large foamy macrophages with normal appearing nuclei, and large cells with hyperchromatic nuclei that appeared to be tumor cells.

Enzymatically dissociated cells on glass slides were also immunostained with melanoma specific mAb to further establish whether melanoma cells were present. Tumor cells were identified by morphology, to distinguish them from potential admixed host cells. The staining pattern of tumor cells in a series of melanoma CTC derived colony isolates is summarized (Table 1). The majority of samples did not stain with the usual pan-melanoma reactive mAb, but generally marked only with MITF [23]. This nuclear transcription factor is currently believed to be pivotal for melanoma pigment gene regulation [24], as well as regulating melanoma proliferation versus differentiation [25] [26]. This observation also is supported by a prior study by Koyanagi et al., who found that PCR-based detection of MITF in blood correlated with an adverse outlook in advanced melanoma patients [27].

\subsection{Flow Cytometric Analysis of CTC Derived Colony Cells}

Since many of the cells isolated from CTC cultures did not react with a customary panel of pan-melanoma antibodies, we desired a more stringent level of proof that the cultured cells were indeed cancer cells. Single cell suspensions were stained for DNA content and analyzed by flow cytometry to identify diploid (normal) and aneuploid (tumor) populations. Flow cytometry confirmed that both diploid and aneuploid cell populations could be identified and quantified from within CTC-derived colonies in all samples (Figure 2(a)). The aneuploid cells could be characterized as being larger and more granular than diploid cells by forward and side scatter on flow cytometry (Figure 2(b)). In addition, specific mAb staining with gating on the aneuploid populations established that this population stained with the stem cell marker aldehyde dehydrogenase ALDH1A1. This antibody did not stain diploid cells in the culture (Figure 2(c)). The flow cytometric analysis of DNA content and ALDH1A1 expression in 3 melanoma CTC-derived isolates is summarized (Table 2). Further flow cytometry experiments showed that the aneuploid cells in colonies as well as diploid cells reproducibly stained with the putative hematopoietic cell marker CD45 (Figure 2(d)). Currently CD45 is assumed to mark only bone marrow derived blood cells and not solid tumor-derived cells, like melanoma. Our data shows that many CTC-derived tumor cells in colonies also share CD45 expression. Therefore CD45 is not specific to peripheral blood cells and investigators should be careful about using this marker to distinguish normal cells from neoplastic cells. 


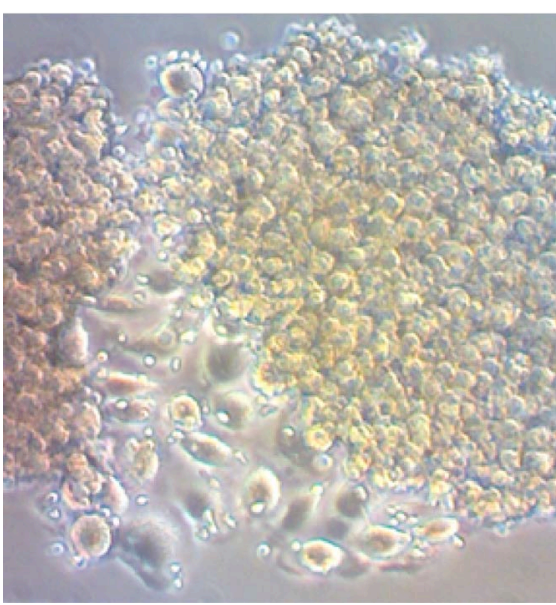

(a)

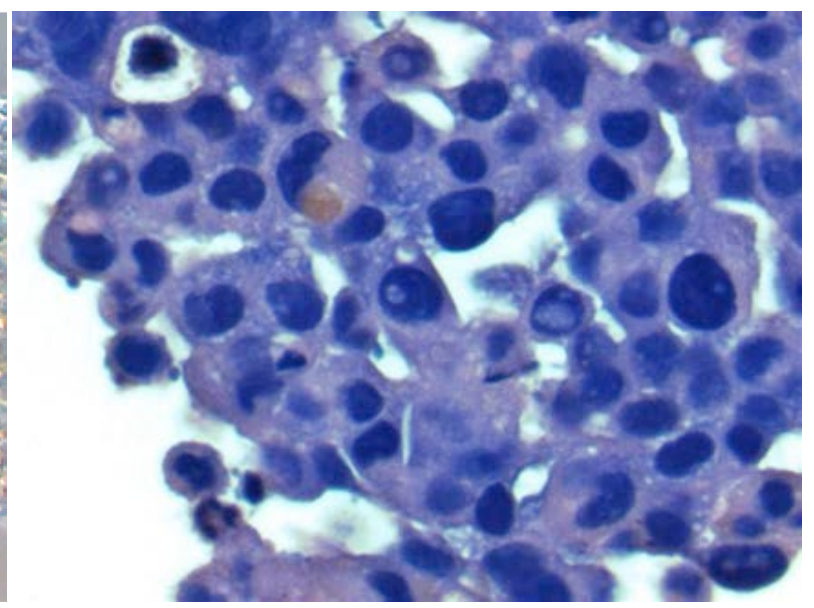

(b)

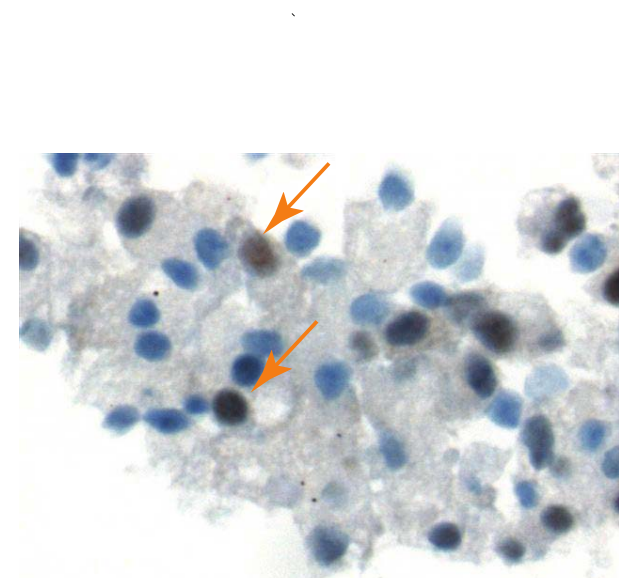

(c)

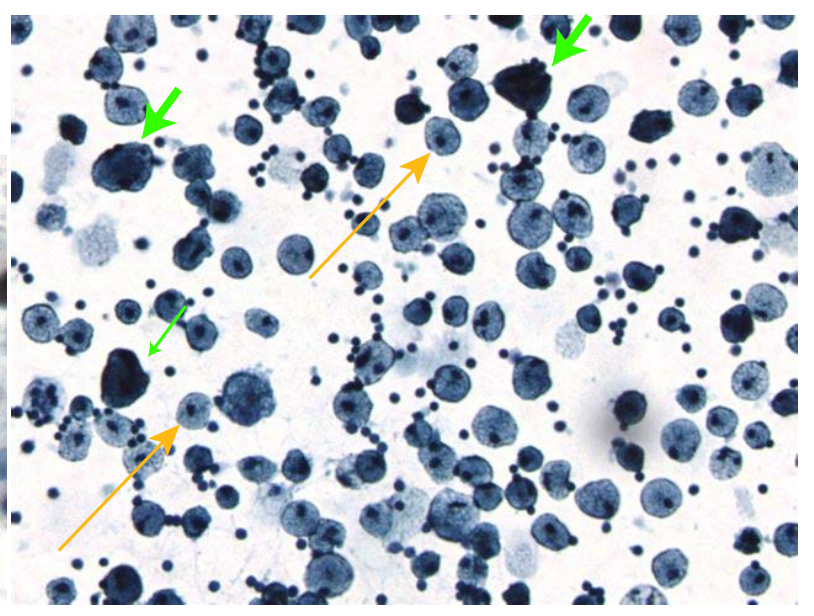

(d)

Figure 1. Culture and staining of melanoma CTC-derived colonies. The buffy coat was separated from $10 \mathrm{ml}$ blood by Ficoll-Hypaque centrifugation, then split into 8 replicate cultures in TrueCells medium. After 16 days in a $5 \% \mathrm{CO}_{2}$ incubator, cultures were evaluated for colony growth using an inverted microscope. A typical melanoma colony is shown (10x magnification) (Panel a). Intact CTC-derived colonies were harvested using a sterile micropipette. A total of 20 - 30 pooled colonies were fixed in CytoLyt solution (Hologic, Inc., Marlborough, MA) and embedded in paraffin. A series of $5 \mu \mathrm{m}$ sections were prepared. A slide stained with hematoxylin and eosin was used to evaluate pathology of the tumor spheroids (Panel b). Additional slides were deparaffinized and stained on an automated BenchMark Ultra Staining system with the Optiview DAB hapten detection system. These slides were stained with monoclonal antibodies, including microopthalmia transcription factor (MITF-mAb). The orange arrows indicate nuclear staining of tumor cells (Panel c). Tumor cell containing colonies were also harvested, washed in isotonic saline and treated with Accutase to produce a single cell suspension. After extensive washes, cell smears were prepared by allowing $50 \mu \mathrm{l}$ of the cell suspension to settle onto a glass slide for 30 minutes. After liquid was gently decanted and blotted, slides were air-dried and fixed in 95\% ethanol. Some slides were stained with Papanicolaou stain (Panel d). These slides showed 3 populations of cells: large tumor cells with high nuclear cytoplasmic ratio (green arrows), large macrophages with normal appearing nuclei and foamy cytoplasm (yellow arrows), and a background of smaller leukocytes.

\subsection{Preliminary Characterization of Host-Cell Component in Colonies}

Our experiments demonstrated a variable host cell component in CTC-derived colonies. We initiated characterization of these host-derived leukocytes. We chose a panel of antibodies that would allow us to identify the derivation of these host cells. Histologic sections of CTC-derived spheroids were stained by immune histochemistry using rabbit mAb directed against CD68 (pan-macrophage), CD31 (endothelial cells), CD43 (PMN, monocytes, histiocytes), CD3 (T cells), as well as CD45 (putative pan hematopoietic cell).

Morphologically, the CTC-derived colonies exhibited three distinct cell types: In every sample that grew co- 
Table 1. Immunostaining of dissociated CTC-derived colonies.

\begin{tabular}{|c|c|c|c|}
\hline Patient & HMB-45 & MART-1 & MITF \\
\hline M001 & - & - & + \\
\hline M002 & - & - & + \\
\hline M005 & - & - & + \\
\hline M008 & - & - & \pm \\
\hline M009 & - & - & - \\
\hline M010 & - & - & + \\
\hline M011 & - & + & - \\
\hline M012 & + & + & + \\
\hline
\end{tabular}

-: no staining; +: positive staining in a subpopulation of cells; \pm : equivocal staining. Tumor colonies were harvested, washed in isotonic saline and briefly incubated with Accutase to produce a single cell suspension. After additional washes, $50 \mu$ l of the cell suspension was allowed to settle onto a glass slide for 30 minutes. After media was gently decanted and blotted, slides were air-dried and fixed in 95\% ethanol. Cells were stained with the monoclonal antibody shown using a BenchMark Ultra Staining system and the Optiview DAB hapten detection system.

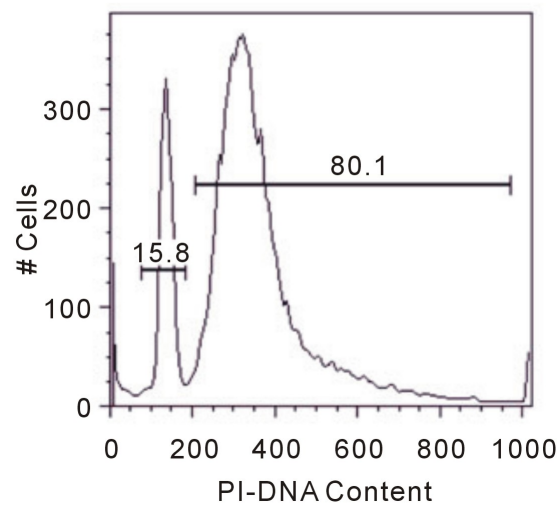

(a)

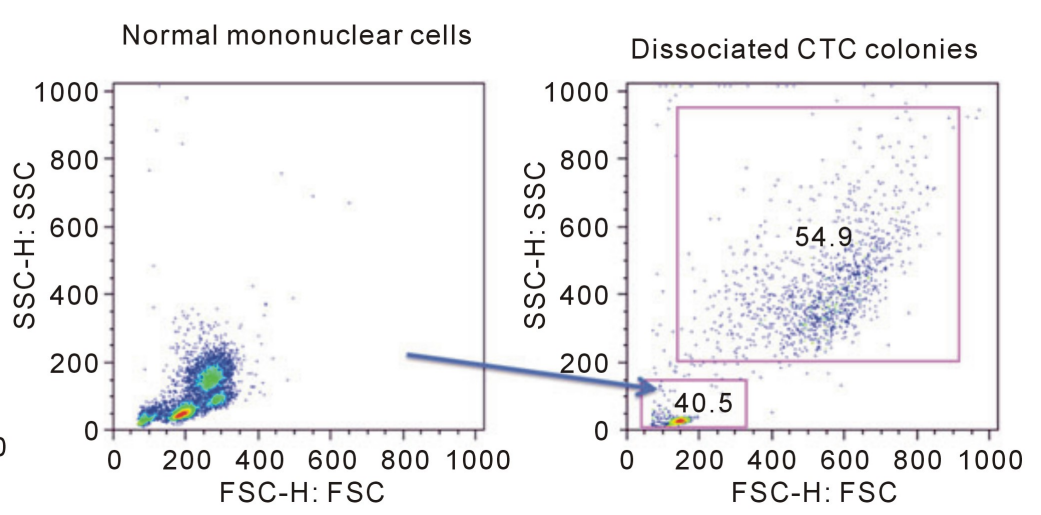

(b)

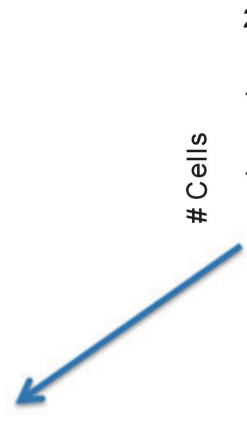

Diploid Peak

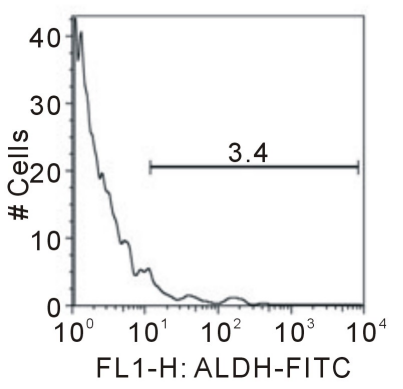

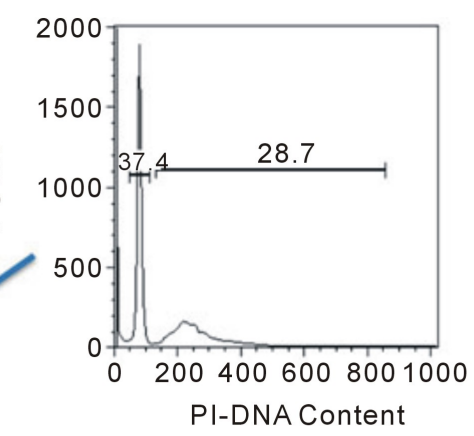

PI-DNA Content

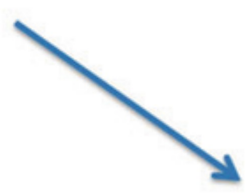

Aneuploid Peak

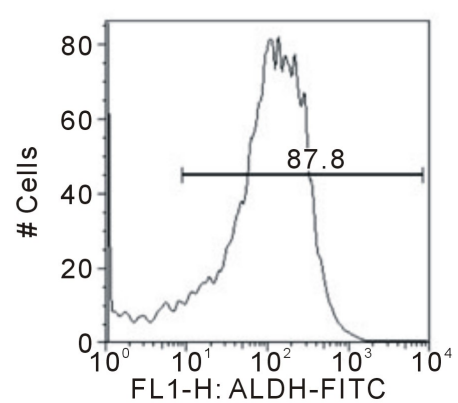

(c) 

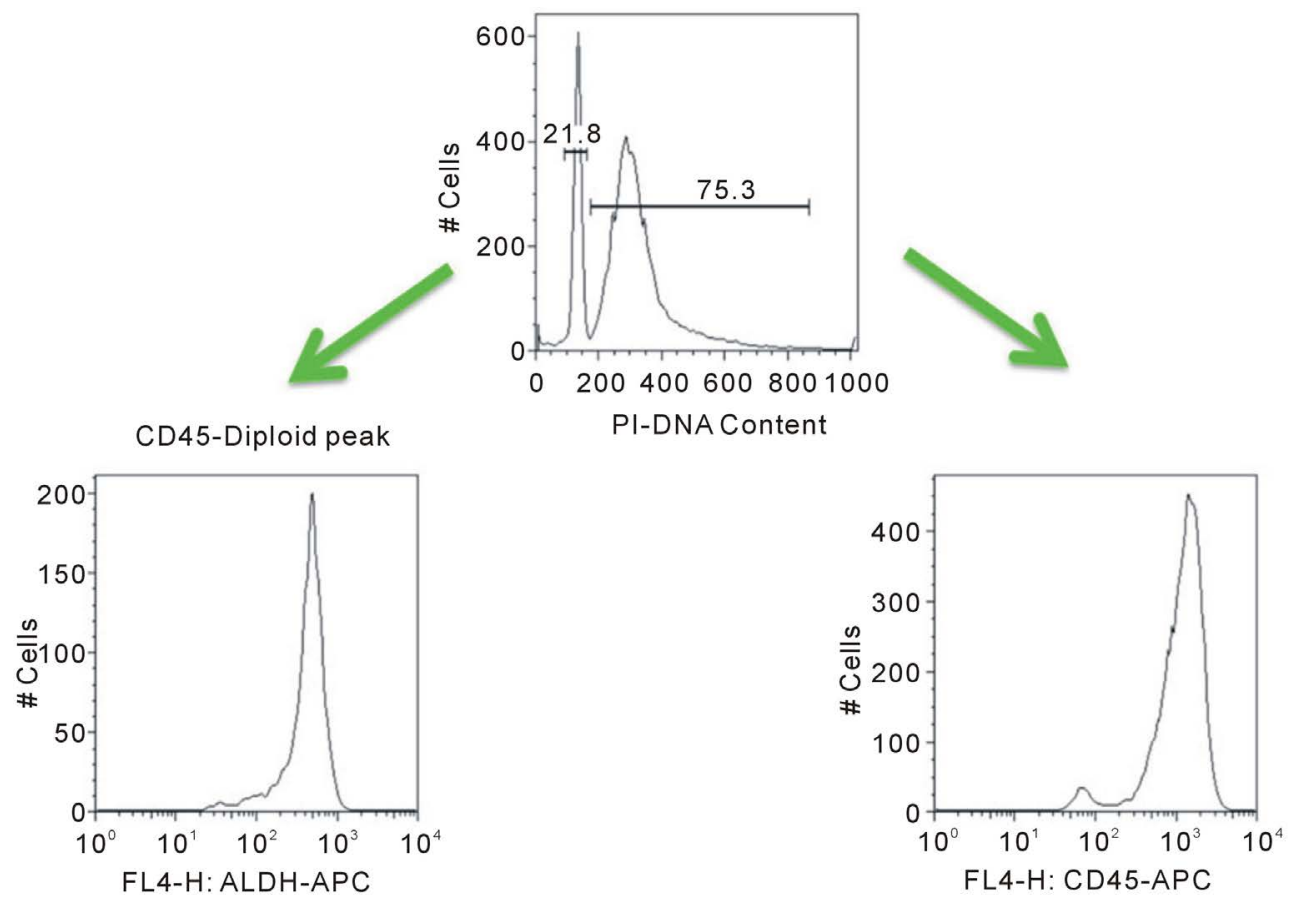

(d)

Figure 2. Flow cytometric analysis of CTC-derived colony cells. A single cell suspension of cultured CTC-derived cells was prepared and cells were fixed (BD Cytofix/Cytoperm). Cells were treated with $200 \mu \mathrm{g} / \mathrm{ml}$ RNAse for 10 minutes. Propidium iodide was added at a final concentration of $50 \mu \mathrm{g} / \mathrm{ml}$ for at least 5 minutes. Twenty thousand events were analyzed per sample using a FACSCalibur flow cytometer and data was analyzed using FlowJo (Ashland, OR) software. Data was plotted showing PI fluorescence on a linear scale for quantification of the percentage of aneuploid or diploid cells (Panel a). Normal human leukocytes (diploid DNA) served as controls to establish gating by forward and side scatter. The larger size and granularity of tumor cells found in CTC-derived cultures was established (Panel b, upper gate). Separate samples of cells were dual-stained for the stem cell marker ALDH1A1 (Panel c) and the pan-leukocyte marker CD45 (Panel d) along with PI. Samples were gated on the diploid and aneuploid DNA cell populations. ALDH1A1 expression was completely restricted to the aneuploid cells. In contrast, CD45 was equally expressed in diploid and aneuploid cells.

Table 2. Summary of flow cytometric analysis of melanoma CTC-derived colonies.

\begin{tabular}{|c|c|c|c|c|c|c|}
\hline Sample & M15c & M057 & M058 & IS 008 & MNC & M14 line \\
\hline Aneuploid (\%) & 35.8 & 20.4 & 45.5 & 55.9 & 0.04 & 95.6 \\
\hline Diploid (\%) & 46.2 & 75 & 39.9 & 41.8 & 97.8 & 0.82 \\
\hline ALDH1A1 (\%) & 3.3 & 26.4 & 85.5 & 7 & 0.63 & 8.6 \\
\hline Aneuploid & 17.2 & 89.3 & 51.6 & 87.8 & 0 & 5.77 \\
\hline Diploid & 1.15 & 0.43 & 3.4 & 1.83 & 0.58 & 0.5 \\
\hline CD45 (\%) & 93.2 & ND & 98.1 & 92.4 & 94 & 1.35 \\
\hline Aneuploid & 99.3 & ND & 98.8 & 99.6 & 0 & 1.1 \\
\hline Diploid & 97.2 & ND & 97.5 & 90.6 & 98.6 & 0.06 \\
\hline
\end{tabular}

A single cell suspension prepared from CTC-derived colony cells was stained with either ALDH1A1 or APC-conjugated anti-CD45 mAb at $5 \mu \mathrm{g} / \mathrm{ml}$ for $30 \mathrm{~min}$, followed by extensive washes. Cells were subsequently fixed, permeabilized, and stained with propidium iodide. The cell suspension was then analyzed using a flow cytometer. Data analysis was subsequently performed using FlowJo software (TreeStar, Inc.) on a linear scale for DNA analysis. Gating on the aneuploid or diploid cell populations was used to calculate the percentage of cells that stained in each immunostained cell subset. Unstained cells (CD45) and cells stained with primary antibody alone (ALDH1A1) served as a negative control. Normal mononuclear cells (MNC) and the M14 melanoma cell line served as specificity controls.

lonies, there were large tumor cells, with hyperchromatic nuclei that had abnormal DNA content. In addition there appeared to be two types of host cells represented 1) Large cells, with a small, round, and eccentrically placed normal nuclei with abundant foamy-vacuolated cytoplasm on H \& E stain (Figure 3(a)), that stained with 


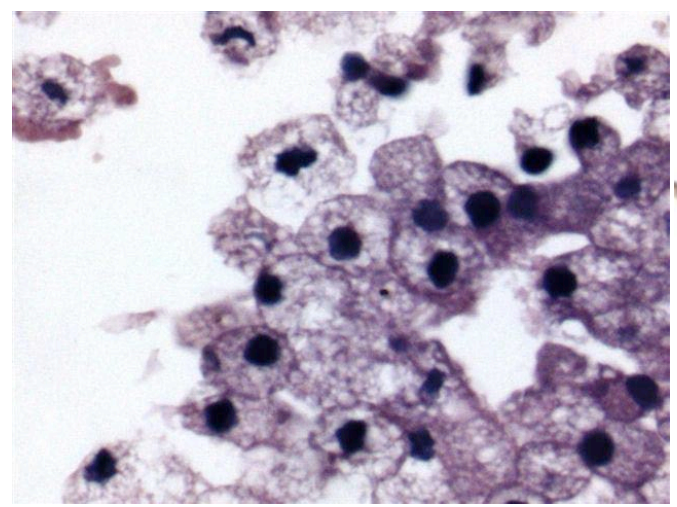

(a)

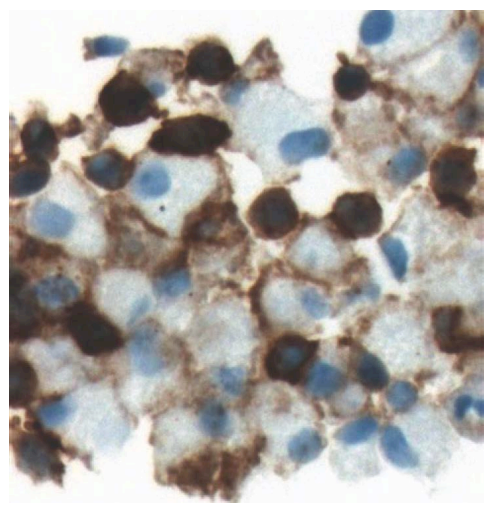

(c)

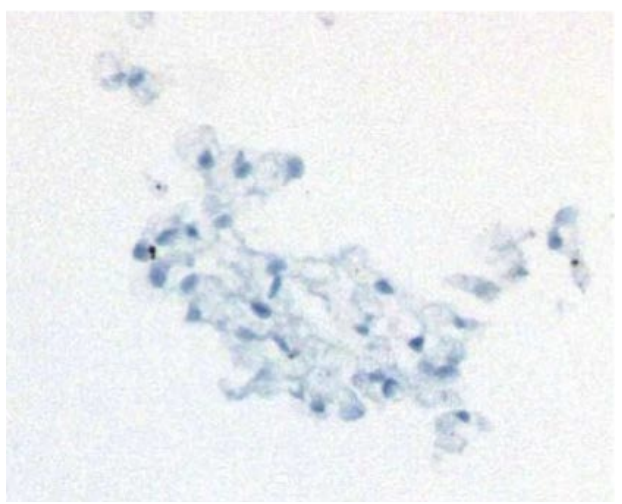

(e)

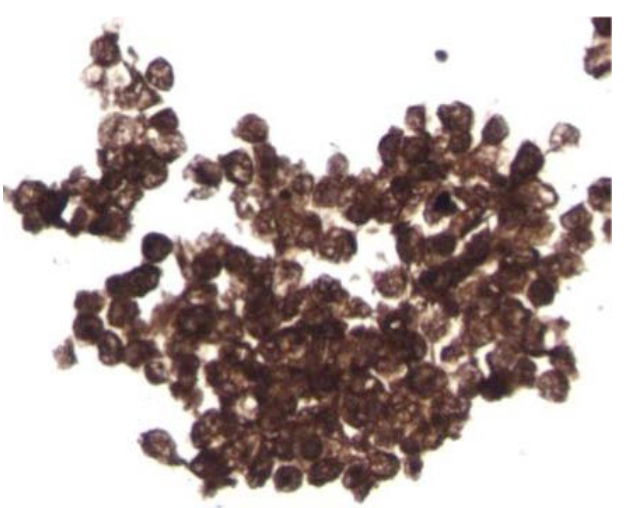

(b)

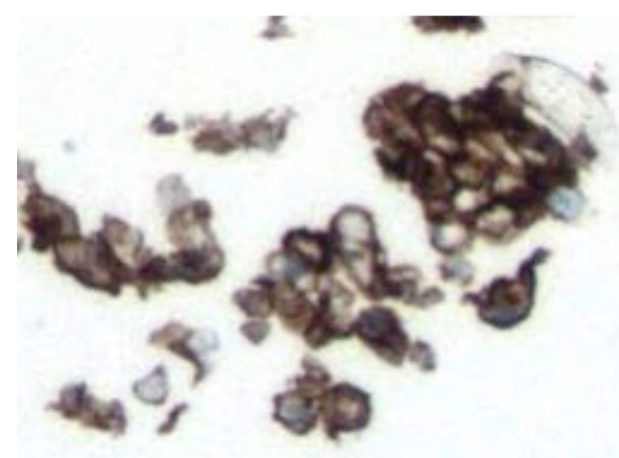

(d)

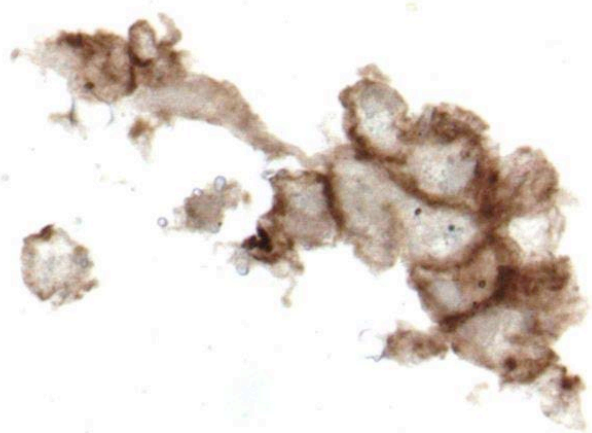

(f)

Figure 3. Host leukocyte contribution to melanoma CTC-derived colonies. Histologic sections of melanoma CTC-derived colonies were prepared as described. Preliminary evaluation showed that CTC-derived colonies exhibited three distinct types of cell morphology: 1) Large sized cells, with hyperchromatic nuclei that stained with the melanoma markers; 2) Large cells, with a small, round, and eccentrically placed nuclei with abundant foamy-vacuolated cytoplasm on H\&E staining (Panel a) that stained with the pan-macrophage marker CD68 (Panel b); 3) A population of small mononuclear cells that stained strongly with the pan-hematopoietic cell markers CD45 (Panel c) and CD43 (Panel d). CD45 staining showed a complex pattern of staining, with strong staining of small cells, which were presumably leukocytes, membrane staining of some larger cells (tumor cells), and no staining of other large cells. The small mononuclear cells did not stain with the T-cell marker CD3 (Panel E) or the endothelial cell antibody CD31 (Panel F).

the pan-macrophage marker CD68 (Figure 3(b)), and 2) a background population of small mononuclear cells that stained strongly with the pan-hematopoietic cell markers CD45 (Figure 3(c)) and CD43 (Figure 3(d)). These small mononuclear cells did not stain with the T-cell marker CD3 (Figure 3(e)) or the endothelial cell antibody CD31 (Figure 3(f)). 


\subsection{Development of an in Vitro Model for CTC Derived Colony Formation}

A preliminary experiment was performed to evaluate the potential role of host leukocytes in tumor colony formation. Cells from the MALME tumor cell line were adapted to grow directly in TrueCells medium. It was observed that the efficiency of tumor colonies formation was low. A total of $5 \times 10^{5}$ or $10^{6}$ MALME cells needed to be plated for appreciable numbers of colonies to form. Colony growth was enhanced when serial dilutions of MALME cells were co-cultured with a fixed number of leukocytes from a normal donor. Colony growth from low numbers of tumor cells, down to as low as 100 tumor cells/sample, was enhanced by the presence of normal leukocytes (Table 3). In contrast, unsupported MALME cells did not form any colonies below $10^{5}$ cells/culture. This suggests that cancer cells by themselves are not very efficient at forming colonies, but a subpopulation of normal host leukocytes may be required to enhance colony growth. Further studies will be needed to better understand the cell types involved and the mechanism by which tumor colony growth is supported.

\section{Discussion}

The "Holy Grail" of cancer treatment is the ability to easily obtain repeated samples of tumor cells from cancer patients before and after treatment to assess response to drug therapies. This novel CTC culture technology provides a tool for easily repeated, minimally invasive fluid biopsies of each patient's cancer at various times merely by obtaining samples of peripheral blood. This technology allows viable cancer cells to be freshly isolated and expanded for analysis using a variety of standard biochemical and molecular techniques.

Another advantage of this current culture approach is that there is no a priori selection with mAb or other processing that might bias the type of tumor cells that are recovered. The entire buffy coat is separated using Ficoll/Hypaque and placed into culture. No exogenouscytokines are added to the culture that would drive differentiation or selection of cells. At the end of a 16-day culture period, each culture dish is scored semi-quantitatively (growth or no growth) or quantitatively (number of tumor colonies/10 ml blood). Tumor cell colonies can then be recovered for further characterization. Colonies can be individually harvested using a sterile micropipette for clonal comparison or an entire plate can be harvested for larger cell yield (e.g., for flow cytometry, immunostaining, PCR-based, genomic, or proteomic analyses). In this manuscript, we describe the isolation, culture and characterization of CTC-derived colonies in melanoma patients. Customary lineage specific immunostains were not useful for identifying cancer cells within the colonies. Reverting to older concepts in cell biology, like the size, granularity and nuclear/cytoplasmic ratio of the cells was more helpful in identifying tumor cells. Nuclear morphology, using Papanicolaou staining, was also useful. Rigorous characterization of tumor cells required flow cytometric analysis. Tumor cells were aneuploid and contained a subset of ALDH1A1 stained cells (putative tumor stem cells). Preliminary characterization suggested that the host cell population was diploid and marked with CD68, CD43, but not CD3. Both host and tumor cells stained with CD45. This phenotype is similar to tumor-associated macrophages that have been shown to promote experimental metastases [28], a functionally distinct subset from traditional cytotoxic macrophages [29]. Utilization of these properties is likely to allow separation of host and tumor cells, using flow cytometric cell sorting.

Our preliminary experiment suggested that host leukocytes might be necessary to support CTC-derived colony growth, particularly in the presence of low numbers of tumor cells. This supports a body of work that suggests a role for host macrophages in the formation of metastases in vivo [28] [29]. Further work will be needed to determine whether these cells provide soluble or contact-mediated support for colony growth. We also

Table 3. Co-culture of MALME melanoma cells with $10^{6}$ normal leukocytes.

\begin{tabular}{ccccccc}
\hline Group & \multicolumn{7}{c}{ Tumor cells } \\
\hline MALME + MNC & $\mathbf{1 0}^{\mathbf{6}}$ & $\mathbf{1 0}^{5}$ & $\mathbf{1 0}^{\mathbf{4}}$ & $\mathbf{1 0}^{\mathbf{3}}$ & $\mathbf{1 0}^{\mathbf{2}}$ & MNC Only \\
\hline Colonies (Mean \pm SD) & $31.3 \pm 2.3$ & $17 \pm 2$ & $6.3 \pm 3.2$ & $1 \pm 1$ & $4.7 \pm 2.5$ & $1.7 \pm 0.6$ \\
\hline MALME Only & $\mathbf{1 0}^{\mathbf{6}}$ & $\mathbf{1 0}^{5}$ & $\mathbf{1 0}^{\mathbf{4}}$ & $\mathbf{1 0}^{\mathbf{3}}$ & $\mathbf{1 0}^{\mathbf{2}}$ \\
\hline Colonies (Mean \pm SD) & $148 \pm 8$ & $1.7 \pm 1.2$ & 0 & 0 & 0 \\
\hline
\end{tabular}

MALME tumor cells were gradually adapted to grow directly in TrueCells medium. The efficiency of tumor colonies formation was low. To model the potential role of host leukocytes, serial 10-fold dilutions of MALME cells were co-cultured with a fixed number $\left(10^{6}\right)$ of normal donor leukocytes. A significant supportive effect for colony formation was seen down to as low as 100 tumor cells. In contrast, MALME cells without added leukocytes did not form colonies below $10^{5}$ cells/culture. This suggests that normal leukocytes contributed to more efficient colony formation when low numbers of tumor cells were present. 
need to perform further studies to characterize which leukocyte subset is involved and whether soluble mediators are required.

The mere detection of tumor cell colonies by culture assay is likely to be an adverse marker and will correlate directly with the prognosis of the patient. It is expected that an elevated number of colonies will relate directly to the risk of that patient dying of cancer. We believe that a CTC culture assay is likely to predict progression-free and overall survival following treatment (predictive value) [30]. Other CTC assays yield only minute numbers of cells, most of which are badly damaged and non-viable, limiting their usefulness for further biologic study. The one commercial CTC assay is only FDA approved for 3 cancers, and typically yields 0 - 100 cells. Our experiments suggest one potential explanation for this low CTC yield is that many of the aneuploid tumor cells actually express CD45 and are being excluded from analysis. This finding was previously suggested by other investigators who isolated CTC using OncoQuick density separation tubes [31].

EpCAM based CTC identification has not been useful in cancers like melanoma, renal cancer, neuroendocrine carcinoma, or sarcoma, because these cancers don't express this antigen. Even in EpCAM expressing tumors, current CTC assays may be challenging. For example, a percentage (5\% - 15\%) of breast, colon, and prostate cancers express low levels of EpCAM, making their CTC difficult to detect by CellSearch assays [18]. It is also suspected that there may be substantial quantitative variability in EPCAM expression on individual CTC within each patient.

CTC are particularly important because they may have cancer "stem cell" properties and represent the actual tumor cells that are in the act of metastasizing [32]. The tumor "stem cell" concept remains somewhat controversial [33] [34], because "stem cells" may not represent a fixed developmental step during hierarchical tumor cell differentiation. They could be dynamically and bidirectionally regulated by the tumor cell microenvironment [35]. It is highly likely that the least differentiated tumor cells that possess "tumor stem cell" properties are not recognized in EpCAM based CTC assays at all [36] [37]. Our experiments suggest that the majority of cultured melanoma CTC do not express the differentiation antigens normally expressed by the bulk melanoma cells in tissue biopsies [31]. Based on these observations, this CTC culture assay is likely to be applicable to a very broad number of cancers currently not testable for CTC by conventional methods.

The novel CTC culture technology opens the door to an assay that can help physicians make treatment decisions and monitor a patient's cancer through the initial diagnosis and treatment, as well as remission and relapse cycles. This assay can be an indicator of treatment response or a harbinger of a patient's decline. We have tested samples from patients who appear to be in clinical and radiographic remission but grow CTC-derived colonies, raising questions about the current definitions of remission and cancer staging [30].

Our results also raise new questions about the mechanism of tumor metastases. More extended follow-up of these patients is needed to understand the clinical implication of low numbers of CTC-derived colonies and the threshold for eventual relapse. The ability to perform repeated fluid biopsies of tumor cells from easily and inexpensively obtainable blood samples opens the door to a novel type of long-term clinical monitoring. We believe this CTC derived culture technology will facilitate repeated isolation of tumor samples for molecular characterization, assessment of treatment response, and observation of changes in drug sensitivity and resistance, with the goal of improving long-term cancer patient survival.

\section{Acknowledgements}

The Genomics Core Facility of UNLV is supported by grants from the National Center for Research Resources (5P20RR016464-11) and the National Institute of General Medical Sciences (8P20GM103440-11).

We would like to acknowledge the patients who volunteered to participate in this study. Dr. Samlowski's clinic nurse, Sherry Neal, RN, and our clinical trials nurse, Priscilla Sandoval, RN, who helped obtain samples for testing. Shane Varney, study coordinator, managed patient data entry. Merle Witter, CCRP helped write the clinical trial protocol and maintained regulatory approval.

Wolfram Samlowski and John McGregor have filed a patent describing the CTC culture method. WE Samlowski, ST Samlowski, and JR McGregor are founders and stockholders in TrueCells LLC.

\section{References}

[1] Bernards, R. and Weinberg, R.A. (2002) A Progression Puzzle. Nature, 418, 823. http://dx.doi.org/10.1038/418823a

[2] Jemal, A., Siegel, R., Ward, E., Hao, Y., Xu, J. and Thun, M.J. (2009) Cancer Statistics, 2009. CA: A Cancer Journal 
for Clinicians, 59, 225-249. http://dx.doi.org/10.3322/caac.20006

[3] Pantel, K. and Alix-Panabieres, C. (2007) The Clinical Significance of Circulating Tumor Cells. Nature Clinical Practice Oncology, 4, 62-63. http://dx.doi.org/10.1038/ncponc0737

[4] Alunni-Fabbroni, M. and Sandri, M.T. (2010) Circulating Tumour Cells in Clinical Practice: Methods of Detection and Possible Characterization. Methods, 50, 289-297. http://dx.doi.org/10.1016/j.ymeth.2010.01.027

[5] Balzar, M., Winter, M.J., de Boer, C.J. and Litvinov, S.V. (1999) The Biology of the 17-1A Antigen (Ep-CAM). Journal of Molecular Medicine, 77, 699-712. http://dx.doi.org/10.1007/s001099900038

[6] Bertazza, L., Mocellin, S. and Nitti, D. (2008) Circulating Tumor Cells in Solid Cancer: Tumor Marker of Clinical Relevance? Current Oncology Reports, 10, 137-146. http://dx.doi.org/10.1007/s11912-008-0022-y

[7] Allard, W.J., Matera, J., Miller, M.C., Repollet, M., Connelly, M.C., Rao, C., et al. (2004) Tumor Cells Circulate in the Peripheral Blood of All Major Carcinomas but Not in Healthy Subjects or Patients with Nonmalignant Diseases. Clinical Cancer Research, 10, 6897-6904. http://dx.doi.org/10.1158/1078-0432.CCR-04-0378

[8] Cristofanilli, M., Budd, G.T., Ellis, M.J., Stopeck, A., Matera, J., Miller, M.C., et al. (2004) Circulating Tumor Cells, Disease Progression, and Survival in Metastatic Breast Cancer. The New England Journal of Medicine, 351, 781-791. http://dx.doi.org/10.1056/NEJMoa040766

[9] de Bono, J.S., Scher, H.I., Montgomery, R.B., Parker, C., Miller, M.C., Tissing, H., et al. (2008) Circulating Tumor Cells Predict Survival Benefit from Treatment in Metastatic Castration-Resistant Prostate Cancer. Clinical Cancer Research, 14, 6302-6309. http://dx.doi.org/10.1158/1078-0432.CCR-08-0872

[10] Cohen, S.J., Punt, C.J., Iannotti, N., Saidman, B.H., Sabbath, K.D., Gabrail, N.Y., et al. (2008) Relationship of Circulating Tumor Cells to Tumor Response, Progression-Free Survival, and Overall Survival in Patients with Metastatic Colorectal Cancer. Journal of Clinical Oncology, 26, 3213-3221. http://dx.doi.org/10.1200/JCO.2007.15.8923

[11] Goodman Jr., O.B., Fink, L.M., Symanowski, J.T., Wong, B., Grobaski, B., Pomerantz, D., et al. (2009) Circulating Tumor Cells in Patients with Castration-Resistant Prostate Cancer Baseline Values and Correlation with Prognostic Factors. Cancer Epidemiology, Biomarkers \& Prevention, 18, 1904-1913. http://dx.doi.org/10.1158/1055-9965.EPI-08-1173

[12] Allen-Mersh, T.G., McCullough, T.K., Patel, H., Wharton, R.Q., Glover, C. and Jonas, S.K. (2007) Role of Circulating Tumour Cells in Predicting Recurrence after Excision of Primary Colorectal Carcinoma. British Journal of Surgery, 94, 96-105. http://dx.doi.org/10.1002/bjs.5526

[13] Hayes, D.F., Cristofanilli, M., Budd, G.T., Ellis, M.J., Stopeck, A., Miller, M.C., et al. (2006) Circulating Tumor Cells at Each Follow-Up Time Point during Therapy of Metastatic Breast Cancer Patients Predict Progression-Free and Overall Survival. Clinical Cancer Research, 12, 4218-4224. http://dx.doi.org/10.1158/1078-0432.CCR-05-2821

[14] Danila, D.C., Heller, G., Gignac, G.A., Gonzalez-Espinoza, R., Anand, A., Tanaka, E., et al. (2007) Circulating Tumor Cell Number and Prognosis in Progressive Castration-Resistant Prostate Cancer. Clinical Cancer Research, 13, 7053-7058. http://dx.doi.org/10.1158/1078-0432.CCR-07-1506

[15] Stott, S.L., Hsu, C.H., Tsukrov, D.I., Yu, M., Miyamoto, D.T., Waltman, B.A., et al. (2010) Isolation of Circulating Tumor Cells Using a Microvortex-Generating Herringbone-Chip. Proceedings of the National Academy of Sciences of the United States of America, 107, 18392-18397. http://dx.doi.org/10.1073/pnas.1012539107

[16] Zheng, S., Lin, H.K., Lu, B., Williams, A., Datar, R., Cote, R.J., et al. (2011) 3D Microfilter Device for Viable Circulating Tumor Cell (CTC) Enrichment from Blood. Biomedical Microdevices, 13, 203-213. http://dx.doi.org/10.1007/s10544-010-9485-3

[17] Hsieh, H.B., Marrinucci, D., Bethel, K., Curry, D.N., Humphrey, M., Krivacic, R.T., et al. (2006) High Speed Detection of Circulating Tumor Cells. Biosensors and Bioelectronics, 21, 1893-1899. http://dx.doi.org/10.1016/j.bios.2005.12.024

[18] Rao, C.G., Chianese, D., Doyle, G.V., Miller, M.C., Russell, T., Sanders Jr., R.A., et al. (2005) Expression of Epithelial Cell Adhesion Molecule in Carcinoma Cells Present in Blood and Primary and Metastatic Tumors. International Journal of Oncology, 27, 49-57.

[19] Sieuwerts, A.M., Kraan, J., Bolt, J., van der Spoel, P., Elstrodt, F., Schutte, M., et al. (2009) Anti-Epithelial Cell Adhesion Molecule Antibodies and the Detection of Circulating Normal-Like Breast Tumor Cells. Journal of the National Cancer Institute, 101, 61-66. http://dx.doi.org/10.1093/jnci/djn419

[20] Königsberg, R., Obermayr, E., Bises, G., Pfeiler, G., Gneist, M., Wrba, F., et al. (2011) Detection of EpCAM Positive and Negative Circulating Tumor Cells in Metastatic Breast Cancer Patients. Acta Oncologica, 50, 700-710. http://dx.doi.org/10.3109/0284186X.2010.549151

[21] Yu, M., Stott, S., Toner, M., Maheswaran, S. and Haber, D.A. (2011) Circulating Tumor Cells: Approaches to Isolation and Characterization. Journal of Cell Biology, 192, 373-382. http://dx.doi.org/10.1083/jcb.201010021

[22] Yang, G.C. and Alvarez, I.I. (1995) Ultrafast Papanicolaou Stain. An Alternative Preparation for Fine Needle Aspira- 
tion Cytology. Acta Cytologica, 39, 55-60.

[23] Prieto, V.G. and Shea, C.R. (2011) Immunohistochemistry of Melanocytic Proliferations. Archives of Pathology \& Laboratory Medicine, 135, 853-859.

[24] Lang, D., Lu, M.M., Huang, L., Engleka, K.A., Zhang, M., Chu, E.Y., et al. (2005) Pax3 Functions at a Nodal Point in Melanocyte Stem Cell Differentiation. Nature, 433, 884-887. http://dx.doi.org/10.1038/nature03292

[25] Lister, J.A., Capper, A., Zeng, Z., Mathers, M.E., Richardson, J., Paranthaman, K., et al. (2013) A Conditional Zebrafish MITF Mutation Reveals MITF Levels Are Critical for Melanoma Promotion vs. Regression In Vivo. Journal of Investigative Dermatology, 134, 133-140.

[26] Eccles, M.R., He, S., Ahn, A., Slobbe, L.J., Jeffs, A.R., Yoon, H.S., et al. (2013) MITF and PAX 3 Play Distinct Roles

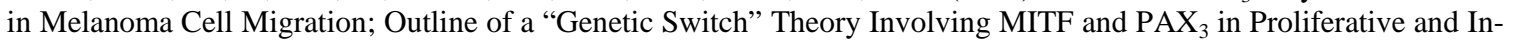
vasive Phenotypes of Melanoma. Frontiers in Oncology, 3, 229. http://dx.doi.org/10.3389/fonc.2013.00229

[27] Koyanagi, K., O’Day, S.J., Gonzalez, R., Lewis, K., Robinson, W.A., Amatruda, T.T., et al. (2006) Microphthalmia Transcription Factor as a Molecular Marker for Circulating Tumor Cell Detection in Blood of Melanoma Patients. Clinical Cancer Research, 12, 1137-1143. http://dx.doi.org/10.1158/1078-0432.CCR-05-1847

[28] Gil-Bernabé, A.M., Ferjančič, S., Tlalka, M., Zhao, L., Allen, P.D., Im, J.H., et al. (2012) Recruitment of Monocytes/ Macrophages by Tissue Factor-Mediated Coagulation Is Essential for Metastatic Cell Survival and Premetastatic Niche Establishment in Mice. Blood, 119, 3164-3175. http://dx.doi.org/10.1182/blood-2011-08-376426

[29] Eljaszewicz, A., Wiese, M., Helmin-Basa, A., Jankowski, M., Gackowska, L., Kubiszewska, I., et al. (2013) Collaborating with the Enemy: Function of Macrophages in the Development of Neoplastic Disease. Mediators of Inflammation, 2013, Article ID 831387. http://dx.doi.org/10.1155/2013/831387

[30] Donepudi, S., Reisinger, S.A., McGregor, J.R., Tharkar, S., Samlowski, S., Ostler, D., et al. (2013) Circulating Tumor Cell Cultures as a Predictive Marker during Salvage Therapy of Refractory Merkel Cell Carcinoma with Chemotherapy and Electron Beam Radiation. Journal of Cancer Therapy, 4, 1162-1166. http://dx.doi.org/10.4236/jct.2013.47135

[31] Clawson, G.A., Kimchi, E., Patrick, S.D., Xin, P., Harouaka, R., Zheng, S., et al. (2012) Circulating Tumor Cells in Melanoma Patients. PLoS ONE, 7, e41052. http://dx.doi.org/10.1371/journal.pone.0041052

[32] Zhang, L., Ridgway, L.D., Wetzel, M.D., Ngo, J., Yin, W., Kumar, D., et al. (2013) The Identification and Characterization of Breast Cancer CTCs Competent for Brain Metastasis. Science Translational Medicine, 5, p. $180 \mathrm{ra} 148$.

[33] Quintana, E., Shackleton, M., Foster, H.R., Fullen, D.R., Sabel, M.S., Johnson, T.M., et al. (2010) Phenotypic Heterogeneity among Tumorigenic Melanoma Cells from Patients That Is Reversible and Not Hierarchically Organized. Cancer Cell, 18, 510-523. http://dx.doi.org/10.1016/j.ccr.2010.10.012

[34] Santini, R., Vinci, M.C., Pandolfi, S., Penachioni, J.Y., Montagnani, V., Olivito, B., et al. (2012) HEDGEHOG-GLI Signaling Drives Self-Renewal and Tumorigenicity of Human Melanoma-Initiating Cells. Stem Cells, 30, 1808-1818. http://dx.doi.org/10.1002/stem.1160

[35] Ni, C. and Huang, J. (2012) Dynamic Regulation of Cancer Stem Cells and Clinical Challenges. Clinical and Translational Oncology, 15, 253-258.

[36] Scheel, C. and Weinberg, R.A. (2011) Phenotypic Plasticity and Epithelial-Mesenchymal Transitions in Cancer and Normal Stem Cells? International Journal of Cancer, 129, 2310-2314. http://dx.doi.org/10.1002/ijc.26311

[37] Joosse, S.A. and Pantel, K. (2013) Biologic Challenges in the Detection of Circulating Tumor Cells. Cancer Research, 73, 8-11. http://dx.doi.org/10.1158/0008-5472.CAN-12-3422 
Supplemental Data: Melanoma Patient Characteristics

\begin{tabular}{|c|c|c|c|c|c|c|c|c|c|c|c|c|}
\hline $\begin{array}{l}\text { Patient } \\
\text { ID }\end{array}$ & $\mathbf{M} / \mathbf{F}$ & Age & $\begin{array}{c}\text { Race/ } \\
\text { Ethnicity }\end{array}$ & Primary & Stage & Mutation & $\begin{array}{l}\text { Date } \\
\text { Drawn }\end{array}$ & $\begin{array}{c}\text { Days } \\
\text { since } \\
\text { Last } R X\end{array}$ & Prior Rx & $\begin{array}{l}\text { CTC } \\
\text { Colonies }\end{array}$ & $\begin{array}{l}\text { Survival } \\
\text { S (Days) }\end{array}$ & $\begin{array}{l}\text { ICurrent } \\
\text { Status }\end{array}$ \\
\hline M-001 & $\mathrm{F}$ & 59 & $\mathrm{~W}$ & Skin & M1c & BRAF V600E & $2 / 7 / 12$ & & None & 66 & 8 & $\mathrm{D}$ \\
\hline M-002 & M & 83 & $\mathrm{~W}$ & Skin & M1c & BRAF V600E & $2 / 8 / 12$ & 14 & $\mathrm{ABC}$ & 188 & 360 & $\mathrm{D}$ \\
\hline M-003 & M & 71 & A & Unk & M1c & $\begin{array}{c}\text { BRAF, CKIT, NRAS } \\
\text { WT }\end{array}$ & 2/9/12 & 22 & Ipi & 12 & 181 & $\mathrm{D}$ \\
\hline M-004 & M & 58 & W & Skin & M1c & $\begin{array}{c}\text { BRAF, CKIT, NRAS } \\
\text { WT }\end{array}$ & 2/9/12 & 6 & Ipi & 89 & 526 & $\mathrm{AWD}^{\dagger}$ \\
\hline M-005 & $\mathrm{F}$ & 82 & W & Skin & M1a & BRAF WT & $2 / 9 / 12$ & & Ipi & 45 & 213 & $\mathrm{D}$ \\
\hline M-006 & $\mathrm{F}$ & 51 & $\mathrm{~W}$ & skin & M1c & BRAF V600E & $2 / 10 / 12$ & & Ipi & 40 & 525 & $\mathrm{CR}^{*}$ \\
\hline M-007 & $\mathrm{F}$ & 58 & $\mathrm{~W}$ & Mucosa & M1c & BRAF, CKIT WT & $2 / 15 / 12$ & & None & 0 & 92 & $\mathrm{D}$ \\
\hline M-008 & M & 45 & $\mathrm{~W}$ & Skin & M1c & BRAF V600E & $3 / 9 / 12$ & & None & 229 & 21 & $\mathrm{D}$ \\
\hline M-009 & M & 75 & $\mathrm{H}$ & Acral & M1a & BRAF WT & $2 / 27 / 12$ & & None & 28 & 508 & CR \\
\hline M-010 & $\mathrm{F}$ & 51 & $\mathrm{~W}$ & Skin & M1a & NRAS G13R & $2 / 29 / 12$ & 0 & ipi & 15 & 469 & $\mathrm{D}$ \\
\hline M-011 & $\mathrm{F}$ & 62 & $\mathrm{~W}$ & skin & M1c & NRAS G61A & $3 / 8 / 12$ & & None & 6 & 50 & $\mathrm{D}$ \\
\hline M-012 & $\mathrm{F}$ & 66 & $\mathrm{~W}$ & Ocular/skin & M1c & BRAF V600E/WT & $3 / 7 / 12$ & & Ipi & 89 & 499 & $\mathrm{AWD}^{\dagger}$ \\
\hline M-013 & $\mathrm{F}$ & 61 & $\mathrm{~W}$ & Ocular & M1c & BRAF V600E & $3 / 19 / 12$ & & $\mathrm{ABC}$ & 0 & 68 & $\mathrm{D}$ \\
\hline M-014 & $\mathrm{F}$ & 45 & W & skin & $\begin{array}{l}\text { T3aN2a } \\
\text { IIIb }\end{array}$ & NRAS? & $5 / 17 / 12$ & 21 & Ipi & 6 & 428 & NED \\
\hline M-015 & M & 60 & $\mathrm{~W}$ & skin & T2aN3 IIIc & BRAF V600E & $7 / 25 / 12$ & & None & 111 & 359 & NED \\
\hline M-016 & $\mathrm{F}$ & 54 & $\mathrm{~W}$ & unk & M1a & NRAS Q61R & $6 / 5 / 12$ & & None & 6 & 409 & CR \\
\hline M-017 & M & 84 & $\mathrm{~W}$ & unk H\&N & M1c & ND & $6 / 6 / 12$ & & None & 21 & 408 & $\mathrm{NED}^{*}$ \\
\hline M-018 & M & 54 & $\mathrm{H}$ & Eyelid & M1c & BRAF, CKIT WT & $6 / 8 / 12$ & 1 & $\mathrm{ABC}$ & 0 & 371 & $\mathrm{D}$ \\
\hline M-019 & M & 61 & $\mathrm{~W}$ & skin & M1c & BRAF V600E & $6 / 20 / 12$ & & None & 3 & 394 & $\mathrm{NED}^{*}$ \\
\hline M-020 & M & 76 & $\mathrm{~W}$ & Unk & M1c & ND & $12 / 6 / 12$ & & None & ND & 394 & $\mathrm{CR}$ \\
\hline M-021 & M & 63 & $\mathrm{~W}$ & skin & M1c & ND & $6 / 22 / 12$ & & None & 76 & 386 & NED \\
\hline M-022 & M & 63 & W & skin & $\begin{array}{l}\text { T4bN2b } \\
\text { IIIb }\end{array}$ & ND & $6 / 28 / 12$ & & None & 0 & 375 & NED \\
\hline M-023 & F & 84 & $\mathrm{~W}$ & Acral & T4bN3 IIIc & NRAS Q61R & $7 / 9 / 12$ & & None & 3 & 373 & $\mathrm{AWD}^{\dagger}$ \\
\hline M-024 & $\mathrm{F}$ & 57 & W & skin & $\begin{array}{l}\text { T1bN2b } \\
\text { IIIb }\end{array}$ & ND & $7 / 11 / 12$ & 21 & ipi & 127 & 115 & $\mathrm{AWD}^{\dagger}$ \\
\hline M-025 & F & 63 & $\mathrm{~W}$ & Desmoplastic & C T4N2 IIIb & BRAF WT & $7 / 18 / 12$ & & $\mathrm{ABC}$ & 11 & 364 & $\mathrm{D}$ \\
\hline M-026 & M & 59 & $\mathrm{~W}$ & skin & T4N3 IIIc & BRAF V600E & $7 / 20 / 12$ & & None & 83 & 364 & $\mathrm{AWD}^{\dagger}$ \\
\hline M-027 & M & 81 & $\mathrm{~W}$ & skin & $\begin{array}{l}\text { T4bN2 } \\
\text { IIIb }\end{array}$ & ND & $7 / 20 / 12$ & & None & 7 & 364 & $\mathrm{D}$ \\
\hline M-028 & M & 29 & $\mathrm{~W}$ & skin & M1c & ND & $7 / 20 / 12$ & & None & 3 & 361 & CR \\
\hline M-029 & $\mathrm{F}$ & 64 & W & Mucosa & T4N0 IIb & ND & $7 / 23 / 12$ & & None & 229 & 318 & $\mathrm{AWD}^{\dagger *}$ \\
\hline M-030 & M & 81 & $\mathrm{~W}$ & skin & $\begin{array}{l}\text { T4b, N3, } \\
\text { IIb }\end{array}$ & ND & $9 / 4 / 12$ & & None & 119 & 358 & $\mathrm{NED}^{*}$ \\
\hline M-031 & $\mathrm{F}$ & 59 & B & skin & T4bN0 IIb & BRAF V600E & $7 / 26 / 12$ & & None & 3 & 184 & $\mathrm{AWD}^{+*}$ \\
\hline M-032 & $\mathrm{F}$ & 48 & $\mathrm{~W}$ & skin & T4bN0 IIb & ND & $1 / 17 / 13$ & & None & 161 & 347 & NED \\
\hline M-033 & M & 82 & $\mathrm{~W}$ & skin & $\begin{array}{l}\text { T4bNx St } \\
\text { IIb }\end{array}$ & ND & $8 / 6 / 12$ & & None & 6 & 333 & NED \\
\hline M-034 & $\mathrm{F}$ & 51 & W & skin & T3bN3 IIIc & ND & $8 / 20 / 12$ & & None & 28 & 331 & NED \\
\hline M-035 & M & 64 & $\mathrm{~W}$ & skin & M1a & $\begin{array}{c}\text { BRAF, CKIT, NRAS } \\
\text { WT }\end{array}$ & $8 / 22 / 12$ & & None & 108 & 325 & CR \\
\hline M-036 & M & 63 & $\mathrm{~W}$ & Ocular & M1c & monosomy 3 & $8 / 28 / 12$ & & None & 30 & 310 & AWD \\
\hline M-037 & M & 54 & W & Ocular & $\mathrm{T} 2 \mathrm{~b}$ & monosomy 3 & $9 / 12 / 12$ & & None & 19 & 310 & NED \\
\hline M-038 & F & 64 & $\mathrm{~W}$ & skin & M1a & BRAF V600E & $9 / 13 / 12$ & & None & 15 & 308 & AWD \\
\hline
\end{tabular}




\section{Continued}

\begin{tabular}{|c|c|c|c|c|c|c|c|c|c|c|c|c|}
\hline M-039 & $\mathrm{F}$ & 77 & W & skin & T3aNx & $\begin{array}{c}\text { BRAF, CKIT, NRAS } \\
\text { WT }\end{array}$ & $9 / 14 / 12$ & & None & 0 & 287 & $\mathrm{AWD}^{\dagger}$ \\
\hline M-040 & M & 88 & $\mathrm{~W}$ & skin & M1a & BRAF V600E & $10 / 5 / 12$ & & None & 12 & 277 & $\mathrm{AWD}^{\dagger}$ \\
\hline M-041 & $\mathrm{F}$ & 54 & $\mathrm{~W}$ & skin & T4bN3 IIIc & BRAF V600E & $10 / 15 / 12$ & & None & 74 & 275 & CR \\
\hline M-042 & M & 61 & $\mathrm{~W}$ & skin & M1a & BRAF V600E & $10 / 17 / 12$ & & None & 19 & 132 & CR \\
\hline M-043 & M & 70 & $\mathrm{~W}$ & skin & M1c & (inad) & $10 / 19 / 12$ & & None & 170 & 270 & $\mathrm{D}$ \\
\hline M-044 & M & 71 & W & Ocular & M1c & ND & $10 / 23 / 12$ & & None & 174 & 263 & $\mathrm{D}$ \\
\hline M-045 & M & 58 & W & Unk & M1c & $\begin{array}{c}\text { BRAF, CKIT, NRAS } \\
\text { WT }\end{array}$ & $10 / 24 / 12$ & & None & 58 & 263 & $\mathrm{D}$ \\
\hline M-046 & M & 80 & $\mathrm{~W}$ & skin & M1b & BRAF V600E & $10 / 29 / 12$ & & None & 174 & & NED \\
\hline M-047 & M & 47 & $\mathrm{~W}$ & Unk & M1c & (inad) & $12 / 14 / 12$ & & None & 1 & 196 & $\mathrm{AWD}^{\dagger *}$ \\
\hline M-048 & M & 33 & W & acral & $\begin{array}{l}\text { T3bN2a } \\
\text { IIIa }\end{array}$ & BRAF V600E & $12 / 20 / 12$ & & None & ND & 32 & $\mathrm{NED}^{\dagger}$ \\
\hline M-049 & $\mathrm{F}$ & 73 & W & Mucosa & M1b & $\begin{array}{l}\text { BRAF, CKIT } \\
\text { NRAS,WT }\end{array}$ & $1 / 4 / 13$ & 14 & ipi & 6 & 156 & $\mathrm{AWD}^{\dagger}$ \\
\hline M-050 & M & 65 & W & Unk & M1c & BRAF V600E & $1 / 30 / 13$ & & None & 105 & 135 & $\mathrm{D}$ \\
\hline M-051 & $\mathrm{F}$ & 50 & W & skin & $\begin{array}{l}\text { T4bN1a } \\
\text { IIIb }\end{array}$ & ND & $2 / 13 / 13$ & & None & 54 & 127 & NED \\
\hline M-052 & $\mathrm{F}$ & 83 & $\mathrm{H}$ & Mucosa & T4 N3IIIc & BRAF WT, NRAS? & $3 / 6 / 13$ & & None & 14 & 121 & $\mathrm{AWD}^{\dagger *}$ \\
\hline M-053 & M & 65 & W & skin & $\begin{array}{l}\text { T4bN1a } \\
\text { IIIb }\end{array}$ & BRAF V600E & $3 / 14 / 13$ & & None & 161 & 93 & $\mathrm{NED}^{\dagger}$ \\
\hline M-054 & F & 24 & W & skin & M1c & BRAF V600E & $3 / 20 / 13$ & & None & 35 & 92 & $\mathrm{AWD}^{\dagger}$ \\
\hline M-055 & M & 69 & W & skin & M1c & BRAF V600R & $4 / 17 / 13$ & & None & 0 & 85 & $\mathrm{AWD}^{\dagger}$ \\
\hline M-056 & M & 48 & W & skin & M1c & CKIT & $4 / 18 / 13$ & & None & 122 & 57 & $\mathrm{AWD}^{+}$ \\
\hline M-057 & M & 28 & W & skin & $\begin{array}{l}\text { T2aN2b } \\
\text { IIIb }\end{array}$ & BRAF WT & $4 / 25 / 13$ & 14 & ipi & 40 & 11 & $\mathrm{AWD}^{\dagger}$ \\
\hline M-058 & M & 30 & W & skin & M1c & BRAF WT & $5 / 15 / 13$ & & None & 308 & 8 & $\mathrm{AWD}^{\dagger}$ \\
\hline M-059 & $\mathrm{F}$ & 67 & W & skin & M1c & BRAF V600E & 7/8/13 & & None & 123 & 360 & $\mathrm{AWD}^{\dagger}$ \\
\hline M-060 & $\mathrm{F}$ & 63 & W & skin & M1a & BRAF V600E & $7 / 12 / 13$ & 14 & $\mathrm{ABC}$ & 20 & ND & $\mathrm{AWD}^{\dagger}$ \\
\hline
\end{tabular}

ND: not done; $\mathrm{AWD}^{\dagger}$ indicates progressing disease despite therapy; CR: complete response; NED: no evidence of disease after surgery; CR* : converted to complete response with radiotherapy or surgery; D: dead. 
Scientific Research Publishing (SCIRP) is one of the largest Open Access journal publishers. It is currently publishing more than 200 open access, online, peer-reviewed journals covering a wide range of academic disciplines. SCIRP serves the worldwide academic communities and contributes to the progress and application of science with its publication.

Other selected journals from SCIRP are listed as below. Submit your manuscript to us via either submit@scirp.org or Online Submission Portal.
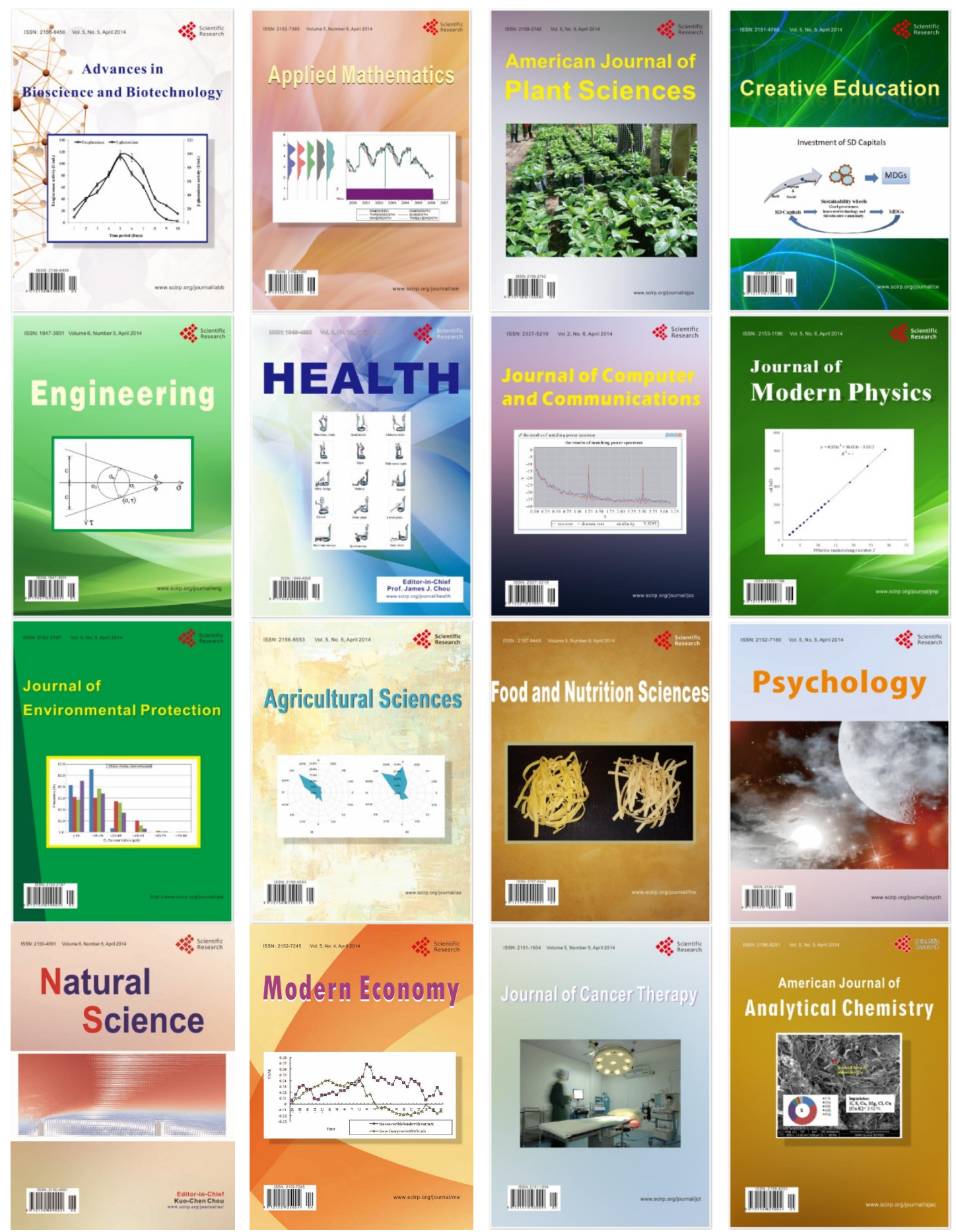